8. Булгакова М., Приступа М. Енергозбереження в Україні: правові аспекти і практична реалізація/ навчально-практичний посібник Наукове видання. Рівне: видавець О.Зень, 2011. 56с.

9. Erik Dahlquist, Iana Vassileva, Eva Thorin, Fredrik Wallin How to save energy to reach a balance between production and consumption of heat, electricity and fuels for vehicles Researcharticle Energy - Mälardalen University, Vasteras, Swedent -Volume 46, Issue 1, October 2012 Pages 16-20.

DOI https://doi.org/10.30525/978-9934-588-79-2-1.39

\title{
ОЦІНКА ЕКОНОМІЧНОЇ ЕФЕКТИВНОСТІ ФУНКЦІОНАЛЬНО ОДНОРІДНИХ ГРУП БІОГАЗОВИХ УСТАНОВОК
}

\author{
Потапенко М. В. \\ кандидат технічних наук, \\ старший викладач кафедри енергетики і автоматики \\ Відокремленого підрозділу Національного університету біоресурсів \\ і природокористування України \\ «Бережанський агротехнічний інститут» \\ Рамші В. Ю. \\ кандидат технічних наук, доцент, \\ завідувач кафедри енергетики і автоматики \\ Відокремленого підрозділу Національного університету біоресурсів \\ і природокористування Украӥни \\ «Бережанський агротехнічний інститут» \\ Шаршонь В. Л. \\ асистент кафедри енергетики і автоматики \\ Відокремленого підрозділу Національного університету біоресурсів \\ і природокористування України \\ «Бережанський агротехнічний інститут» \\ м. Бережани, Тернопільська область, Україна \\ Складність сучасних гетерогенних технологічних систем виробни- \\ цтва біогазу, значні енерго- і металоємності, зростаючі вимоги до \\ якості кінцевого продукту, зумовлюють вибір і застосування систем- \\ ного підходу до техніки розробки біогазових установок.
}


При проектуванні біогазових установок необхідно вже на перших етапах розробити нормативно-методичні матеріали по вибору вихідних параметрів, які забезпечать їх виробництво і експлуатацію з мінімальними затратами засобів і часу. В якості такої основи пропонується використовувати побудовані для однорідних груп біогазових установок (БГУ) параметричні типажі (ряди), тобто упорядковані сукупності числових значень окремих ознак, які характеризують їх конструктивні та експлуатаційні властивості. В першу чергу це відноситься до малогабаритних установок з об'ємом біоректора $3 . .300 \mathrm{~m}^{3}$ [1].

Визначення основних параметрів ряду є лише першим етапом, головне ж полягає у встановленні оптимальної частоти вихідних ознак ряду, тобто частоти визначених параметрів, які забезпечують мінімальні витрати на заданий об'єм робіт - це одноразові капітальні вкладення і поточні експлуатаційні витрати [2, 3]. Ефективність типажу залежить від великого числа факторів як у виробника так і у споживача.

Забезпечення раціональної типології на будь-якому рівні полягає в скороченні ії номенклатури, і досягненні технічної сумісності підсистем, технологічної системи виробництва біогазу, сумісності при їх експлуатації (обслуговуванні, зберіганні, ремонті) забезпеченні комплектуванні парку підсистем в періоди тривалої експлуатації біогазових установок (15-20 років), це дозволяє знизити витрати на експлуатацію, обслуговування за рахунок спеціалізації ремонту, зменшення його тривалості, підвищення готовності обладнання до застосування.

Економічна доцільність може бути виражена двома критеріями: максимумом прибутку і мінімумом затрат [4]. Постановка задачі за мінімумом затрат рахується доцільною, коли виробництво біогазу повинно бути виконано незалежно від ціни реалізації. При визначенні максимального прибутку передбачається, що ціна на газ відома і стійка.

Приведений прибуток визначають за формулою:

$$
\Pi(x)=B(x) \cdot C-3(x) ;
$$

де $\Pi(x)$ - функція економічності типажу $x$;

$B(x)$ - функція валового виробництва біогазу при використанні типажу $x$;

$C$ - середня ціна реалізації біогазу;

$3(x)$ - приведені затрати на створення і експлуатацію типажу $x$.

Перший член виразу (1) означає прибуток від реалізації біогазу із застосуванням типажу $x$ : 


$$
Ц=B(x) \cdot C=\int_{0}^{T} \sum_{K=1}^{K}\left[F\left(x_{K+1}\right)-F\left(x_{K}\right) \cdot C \cdot x_{K}\right] d t ;
$$

Функція затрат:

$$
3(x)=C_{p}(x)+C_{\sigma}(x) \cdot E+C_{e}(x) ;
$$

де $C_{p}(x)$ - функція затрат на розробку проектів БГУ;

$C_{\sigma}(x)$ - функція затрат на виробництво БГУ;

$E$ - нормативний коефіцієнт ефективності капітальних вкладень;

$C_{e}(x)$ - функція затрат на експлуатацію БГУ.

Виходячи з цього функція економічності БГУ буде мати вигляд:

$$
\begin{aligned}
\Pi(x)=\int_{0}^{T} \sum_{K=1}^{K}\left[F\left(x_{K+1}\right)-F\left(x_{K}\right)\right] \cdot C \cdot x_{K} d t-\sum_{K=1}^{K} C_{p}\left(x_{K}\right)-\sum_{K=1}^{K}\left[F\left(x_{K+1}\right)-F\left(x_{K}\right)\right] \cdot C_{\sigma}\left(x_{K}\right) \cdot E- \\
\quad-\int_{0}^{T} \sum_{K=1}^{K}\left[F\left(x_{K+1}\right)-F\left(x_{K}\right)\right] \cdot C_{e}\left(x_{K}\right) d t
\end{aligned}
$$

Обмеження за об’ємом виробництва можна записати таким чином:

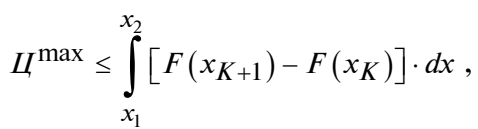

а обмеження по затратах на розробку проектів БГУ визначаються як:

$$
\sum_{K=1}^{K} C_{p}\left(x_{K}\right) \leq C_{p}^{\max }
$$

Застосування даної методики розрахунку дасть можливість значно скоротити терміни при проектуванні біогазових установок та забезпечить їх оптимальні техніко-економічні показники.

\section{Література:}

1. Семененко И .В. Проектирование биогазовых установок. Сумы, ИПП «Мрия-1» ЛТД. 1996. 347 с.

2. Жалдак М.І., Триус Ю.В. Основи теорії і методів оптимізації: Навчальний посібник. Черкаси: Брама-України, 2005. 608 с. 
3. Батищев Д. И. Методы оптимального проектирования : Учеб. пособие для вузов. М. : Радио и связь, 1984. 248 с.

4. Великанов К.М. Расчёты экономической эффективности новой техники: Справочник. Л. : Машиностроение, 1990. 448 с.

DOI https://doi.org/10.30525/978-9934-588-79-2-1.40

NATURAL-LIKE TECHNOLOGIES OF PROTECTION OF RADIO-ELECTRONIC EQUIPMENT FROM THE IMPACT OF POWERFUL ELECTROMAGNETIC RADIATIONS

\author{
Iasechko M. M. \\ Doctor of Technical Sciences, \\ Associate Professor at the Department of Air Defense Armaments \\ of the Land Forces \\ Ivan Kozhedub Kharkiv National Air Force University \\ Piskunov S. \\ Candidate of Technical Sciences, Associate Professor, \\ Head of the Department of Air Defense Armaments of the Land Forces \\ Ivan Kozhedub Kharkiv National Air Force University

\section{Voinov V.} \\ Candidate of Technical Sciences, \\ Senior Lecturer at the Department of Air Defense Armaments \\ of the Land Forces \\ Ivan Kozhedub Kharkiv National Air Force University \\ Kharkiv, Ukraine
}

Development, creation and use of generators with a radiation power of the order of and more than $1 \mathrm{GW}$ with pulse duration of $10^{-9}$ to $10^{-15} \mathrm{sec}-$ onds necessitates the further development of methods and devices for the protection of radio electronic means. This is due to the possibility of both accidental and deliberate (as a result of terrorist acts) use of such generators, which can lead to the REM disruption at considerable distances. At the same time, the threat of REM serviceability disruption is usually created when electromagnetic radiation (EMR) interacts with antennas, communication lines, conductors and radioelements of equipment. This interaction 